\title{
Temperature Effects on Tuber Production and Carbohydrates Partitioning in Different Cultivars During Consecutive Stages of Potato (Solanum tuberosum L.) Growth
}

Khaoula Mokrani ( $\sim$ khaoula.mokrani07@gmail.com)

Vegetable laboratory, Horticulture Department - Higher Agronomic Institute of Chott Meriem, University of Sousse, 4042 Chott Meriem, Tunisia https://orcid.org/0000-0001-6773-2052

Christina Kühn

Institute of Biology, Plant Physiology, Humboldt University, 10115 Berlin, Germany

Neji Tarchoun

Vegetable laboratory, Horticulture Department - Higher Agronomic Institute of Chott Meriem, University of Sousse, 4042 Chott Meriem, Tunisia

\section{Research Article}

Keywords: Solanum tuberosum, Temperature, Carbohydrate partitioning, Enzyme activity, Gene expression, Yield

Posted Date: January 10th, 2022

DOI: https://doi.org/10.21203/rs.3.rs-1243993/v1

License: (c) (7) This work is licensed under a Creative Commons Attribution 4.0 International License. Read Full License 


\section{Abstract}

The main objective of this study was to assess responses of mid-early (Spunta) and mid-late (Bellini) potato cultivars to different temperature regimes during subsequent stages of potato growth. The impact of high temperature $\left(25 / 22^{\circ} \mathrm{C}\right.$ day/night), low temperature $\left(18 / 16^{\circ} \mathrm{C}\right.$ day/night $)$ and intermediate temperature $\left(20 / 18^{\circ} \mathrm{C}\right.$ day/night) was evaluated for different growth stages. Data were obtained for photosynthesis, carbohydrates in leaves, stems and tubers as well as production parameters. Enzyme activities were determined for sucrose-phosphate synthase in leaves, acid invertase in stems and acid and neutral invertases in tubers. Gene expression levels of relevant sugar metabolizing enzymes was quantified.

A detailed correlation analysis revealed a strong impact of the expression level of sugar metabolizing enzymes in leaves on the final number of tubers per plant.

Whereas total tuber yield increases with temperature, the number of tubers per plant was highest under low temperature conditions. Our data suggest an important role of the temperature on the length of the different growth stages.

\section{Key Message}

Re-evaluation of earlier reports regarding temperature effects on potato tuber yield using two different, mid-early and mid-late ripening potato varieties led to unexpected results for most of the determined crop parameters such as carbon partitioning, carbon metabolism, tuber yield and time of tuber maturation.

\section{Introduction}

The Intergovernmental Panel on Climate Change (IPCC 2007) predicts an increase of global temperatures of $2-4^{\circ} \mathrm{C}$ till the end of this century with an average increase of $0.2-0.3^{\circ} \mathrm{C}$ per decade. It is to be expected that this increase in temperature strongly affects crop productivity.

Potato is one of the four most important food crops worldwide and is not only used as nutrient but also for fuel production and production of synthetic industrial products (Kikuchi et al. 2015). However potato plants have only limited biotic stress tolerance (Pino et al. 2007) and is sensitive towards abiotic stresses such as drought, salt, freezing or heat stress (Vasquez-Robinet et al. 2008). A detailed analysis of temperature effect on potato productivity is therefore indispensable.

Potato (Solanum tuberosum L.) grows best under moderate temperature (Van Dam et al. 1996). Generally, tuberization is promoted by long nights, cool temperatures, and low rates of nitrogen supply, and delayed by short nights, high temperatures, and nitrogen-rich fertilization (Rodriguez-Falcon et al. 2006). Optimal tuberization with high weight and number of tubers per plant as well as tubers quality, under low temperatures around $18^{\circ} \mathrm{C}$ and short days with less than 12 hours of light (Rousselle et al. 1996). Rykaczewska (2015) demonstrated that potato plants provide highest growth rate and largest tuber yield at around $20^{\circ} \mathrm{C}$. Winkler (Winkler 1971) reported that a most advantageous temperature for photosynthesis is about $16^{\circ}$ to $20^{\circ} \mathrm{C}$. Those conditions were found to be most suitable for early tuber growth by promoting tuber initiation, which could increase the number of tubers produced per plant (Ewing and Struik 1992). Also growth and bulking are reached earlier at moderate temperatures with a high absolute tuber growth and dry matter partitioning. Contrarily, higher temperatures induce a delay of tuber initiation and bulking, cause lower absolute tuber growth and could stop dry matter distribution to sink organs (Van Dam et al. 1996). It was shown afterwards, that the response of potato cultivars to elevated temperature differs according to the growth stage (Rykaczewska 2015). In spite of the fact that increasing day and night temperatures above optimal levels reduce tuber yield, excessive night temperatures appear to be more detrimental (Gregory 1956). Growing potato plants at elevated temperatures results generally in a decrease in tuber yield (weight and number of tubers) paralleled by an increase in photosynthesis in source leaves. This was accompanied with a remarkable shift between leaf and tuber metabolites (Hancock et al. 2014). Lafta and Lorenzen (Lafta and Lorenzen 1995) demonstrated earlier that high temperature could not affect or increase the photosynthetic rates which increase accumulation of sucrose and decrease starch amounts in source leaves. Transpiration, translocation, photosynthesis and respiration are temperature dependent (Pavlista and Ojala 1997). Other studies confirmed that high temperatures lead to increased photorespiration (Berry and Bjorkman 1980), increased respiration rates and consequently a considerable loss of carbohydrates in sink organs (Farrar and Williams 1991), as well as a reduction of sucrose import into storage sinks (Wolf et al. 1990). Cold stress could damage photosynthetic machinery, including photosystems and photosynthetic pigments, by altering the expression of photosynthetic genes (Oquist and Huner 2003).

Tuberization under optimal conditions of day length less than 12 hours light and temperature about $18^{\circ} \mathrm{C}$ (Rousselle et al. 1996) involves phloem-mobile signals that function in the leaf and move into stolon tips to induce tuber development. The three best candidates for phloem-mobile signals that regulate tuber formation are: CYCLING DOF FACTOR1 (StCDF1) for earliness, StBEL5 mRNA, and SELF-PRUNING6A (StSP6A) protein. It was admitted that an overexpression of StSP6A produces plants that tuberize earlier and consistent with this role of SP6A under non inductive long days (Xu et al. 1998). Navarro et al. (Navarro et al. 2011) found that transgenic overexpression lines tuberize under non-inductive LDs (long days), whereas transgenic suppression lines exhibited a strong reduction in tuber production under SDs (short days). Overexpression of StBEL 5 also enhanced early tuberization and increased tuber yield in response to SD conditions (Banerjee et al. 2006). During the onset of tuberization, StBEL 5 initiate signal activity in leaves with a transcriptional induction of both StCDF1 and StSP6A. Under tuber-inducing conditions (SD conditions), horizontal stolon elongation ceases and the stolon tip begins to swell to form the tuber. Long distance movement of the StBEL5 transcript was recently implicated in the control of tuber induction in response to SDs (Banerjee et al. 2006).

This study was undertaken to determine the physiological, biochemical, enzymatic and genetic behavior of mid-early and mid-late maturing potato cultivars subjected to different temperatures. Experiments were carried out to evaluate relevant parameters concerning photosynthesis (Fo, Fm and Fv/Fm), soluble sugar content and starch accumulation as well as their distribution in source and sink organs, the expression levels and activities of sugar metabolizing enzymes including AGPase, invertases, SPS and sucrose synthase in leaves, stems or tubers, as well as production parameters, in order to determine the optimal temperature for the tuberization according to length of the development cycle of the potato cultivar.

Page 2/17 


\section{Materials And Methods Plant material and growth conditions}

A total of two potato cultivars were obtained by a certified seed production of Technical Center of Potato and Artichoc, Tunisia (TCPA). The tuber seeds were allowed to sprout and later a number of 162 tubers per cultivar were planted. Experiment was conducted in the greenhouse of the Institute of Biology, Humboldt University of Berlin during the months of September to December. The mean photosynthetic photon flux density was about $400 \mu \mathrm{E} \mathrm{m}^{-2} \mathrm{~s}^{-1}$ and additional illumination was provided by high-pressure sodium lamps NATRALOX and metal halide lamps NACHROMA (NARVA GmbH, Berlin Germany) distributed equally in the greenhouse Two additional lamps per $\mathrm{m}^{2}$ with a related luminous Flux (100 Hours). The duration of the light pulse was adjustable depending on the intensity of natural light. A commercial fertilizer was incorporated into the soil ("Einheitserde classic soil" from Profisubstrat) at recommended rate containing ( $\mathrm{N}: 100 \mathrm{~g} / \mathrm{l}, \mathrm{P}_{2} \mathrm{O} 5: 100 \mathrm{~g} / \mathrm{l}, \mathrm{K}_{2} \mathrm{O}: 75 \mathrm{~g} / \mathrm{l}, \mathrm{B}$ (Bor): 0.12g/l, Cu: 0.05g/l, Fe: 0.25g/l, Mn: $\left.0.15 \mathrm{~g} / \mathrm{l}, \mathrm{Mo:} 0.01 \mathrm{~g} / \mathrm{l}, \mathrm{Zn}: 0.04 \mathrm{~g} / \mathrm{l}\right)$. Potato (Solanum tuberosum) plants were grown in pots of $4 \mathrm{I}$ volume, under three different temperature regimes: high temperature condition: $25 / 22^{\circ} \mathrm{C}$ light/dark; low temperature condition: $18 / 16^{\circ} \mathrm{C}$ light/dark; intermediate temperature condition: $20 / 18^{\circ} \mathrm{C}$ light/dark. Each pot contains a potato plant with 4 to 5 stems, with a density of 18 pots per $\mathrm{m}^{2}$.

The experiment was laid out in a Completely Randomized Block design (RCBD), with three replications. Different Measurements were made on 6 plants per cultivar per temperature regime and per date of measure.

Statistical analysis of the various measures was performed by means of the XLSTAT, 2014, according to the analysis of variance. Effect of cultivars and temperature on various characters was analyzed using two-way analysis of variance (ANOVA). A Duncan test was used to identify homogenous group. Correlation coefficients were also calculated using XLSTAT.

\section{Chlorophyll Fluorescence}

Chlorophyll fluorescence was measured with the fluorometer PAM (Fluorescence Monitoring System). This PAM fluorometer automatically measures: Fo, Fm and Fv/Fm. The application of a saturating pulse (light) to a dark-adapted leaf induces a maximum value of fluorescence by closing reaction centers. At this point, there is no NPQ (non-photochemical quenching) in a healthy non-stressed plant because the material has been fully dark-adapted, so the maximal possible value for fluorescence, Fm, is recorded. The difference between Fo and Fm is the variable fluorescence, Fv. It has been shown theoretically and empirically that Fv/Fm constitutes a robust indicator of the maximum quantum yield of PSIl chemistry (Butler 1978; Genty et al. 1992) (For unstressed leaves, the value of Fv/Fm is highly consistent at $\sim 0.83$ and correlates with the maximum quantum yield of photosynthesis (Demmig and Björkman 1987). The presence of any type of stress that causes inactivation damage of PSII (Long et al. 1994) or the induction of sustained quenching (Demmig-Adams and Adams 2006) leads to the lowering of Fv/Fm.

\section{Determination of soluble sugars and starch}

Leaves, stems and tubers were harvested and samples (100-200 mg fresh weight) were immediately frozen in liquid nitrogen. Samples were taken at the end of the light period when the content of soluble sugars in source leaves is highest (Chincinska et al. 2008) and extracted with $1 \mathrm{ml} 80 \%$ ethanol at $80^{\circ} \mathrm{C}$ for $2 \mathrm{~h}$. The supernatant was used for the determination of glucose, fructose and sucrose, as described in Stitt et al. (Stitt et al. 1989). At the bottom of the tube the pellet was created. The pellet was washed three times with $80 \%$ ethanol and then incubated at $70^{\circ} \mathrm{C}$ until drying. Subsequently, samples (leaves, stems and tubers) were homogenized in $800 \mu \mathrm{l} 0.2 \mathrm{M} \mathrm{KOH}$, incubated at $95^{\circ} \mathrm{C}$ for $1 \mathrm{~h}$, adjusted to a neutral pH or slightly acid by adding $140 \mu \mathrm{l} 1 \mathrm{M}$ acetic acid and then centrifuged for $5 \mathrm{~min}$ by $10,000 \mathrm{xg} .50 \mu \mathrm{l}$ of the supernatant were mixed with $100 \mu \mathrm{l}$ amyloglucosidase $(2 \mathrm{mg} / \mathrm{ml} 50 \mathrm{mM}$ sodium acetate buffer, pH 5.0$)$, then incubated over the night at $55^{\circ} \mathrm{C}$. The starch determination was as described in Stitt et al. (1988).

\section{Invertase assay}

Acid and neutral invertase activity was measured in the direction of sucrose degradation. Plant tissue (100 mg), quickly frozen and grinded in liquid nitrogen, was homogenized in $500 \mu$ lextraction buffer (50 mM 4-(2-hydroxyethyl)-1-piperazineethane, sulphonic acid (HEPES-KOH), pH 6.0; 5 mM Mg Cl 2 ; $15 \%$ glycerin; $1 \mathrm{mM}$ ethylene diamine acetate (EDTA); $1 \mathrm{mM}$ ethylene glycol bis ( $\beta$-aminoethylether)-N,N,N',N'-tetraacetic acid (EGTA); $0.1 \mathrm{mM}$ Pefabloc Phosphatase Inhibitor and $5 \mathrm{mM} \beta$-mercaptoethanol). The extract was centrifuged for $15 \mathrm{~min}$ at $4^{\circ} \mathrm{C}, 15,000 \mathrm{xg}$ and the clear supernatant was transferred in a new Eppendorf tube.

For assaying neutral invertases, the reaction mixture contained $50 \mathrm{mM}$ HEPES KOH pH 7.5, $0.5 \mathrm{M}$ sucrose and $20 \mu \mathrm{l}$ of the protein extract in a final volume of $100 \mu \mathrm{l}$. Incubation was carried out at $35^{\circ} \mathrm{C}$ for $1 \mathrm{~h}$ and stopped at $95^{\circ} \mathrm{C}$ for $5 \mathrm{~min}$. Blanks had the same reaction mixture but were heat inactivated without incubation. The determination of glucose and fructose was carried out as described in Stitt et al. (1989).

For acid invertase activity, the reaction mixture contained $50 \mathrm{mM}$ sodium acetate pH 5.0, $0.5 \mathrm{M}$ sucrose and $60 \mu \mathrm{l}$ of the protein extract in a final volume of $100 \mu \mathrm{l}$. Incubation was carried out at $35^{\circ} \mathrm{C}$ for $1 \mathrm{~h}$. To neutralize the reaction mixture before stopping it at $95^{\circ} \mathrm{C}$ for $5 \mathrm{~min}, 10 \mu \mathrm{l}$ of Tris- $\mathrm{HCl} \mathrm{pH} 8.0 \mathrm{were}$ added. Blanks had the same reaction mixture but were heat inactivated without incubation. Glucose and fructose contents were determined as described in Stitt et al. (1989).

\section{Sucrose Phosphate Synthase assay}

SPS activity was measured as described in Huber et al. (1989) with modifications. Plant tissues (100 mg) were extracted after grinding samples in a precooled mortar. Plant material was homogenized in $1 \mathrm{mg}$ of soluble polyvinylpyrrolidon (PVP) in $400 \mu \mathrm{l}$ SPS extraction buffer containing $25 \mathrm{mM} \mathrm{HEPES} \mathrm{KOH} \mathrm{pH} 7.0$, $12 \mathrm{mM} \mathrm{MgCl} 2,0.5$ mM EDTA Na pH 8.0, 8 mM dithiothreitol DTT, $10 \mu \mathrm{M}$ phenylmethane sulfonyl fluoride (PMSF) and 0.1 \% (V/V) Triton X-100. The 
homogenates were centrifuged at $17.000 \mathrm{xg}$ for $1 \mathrm{~min}$ at $4^{\circ} \mathrm{C}$. Complete EDTA-free protease inhibitor was added to the extracts. The reaction mixture contained $50 \mu \mathrm{l}$ of the protein extract, $100 \mu \mathrm{l} \mathrm{SPS}$ assay-buffer $\left(100 \mathrm{mM} \mathrm{HEPES} \mathrm{KOH}, 40 \mathrm{mM} \mathrm{KCl}, 10 \mathrm{mM} \mathrm{MgCl}_{2}\right.$ ) and $50 \mu$ respective substrate: $\mathrm{V}_{\text {sel }}(24.4 \mathrm{mg}$ UDP-

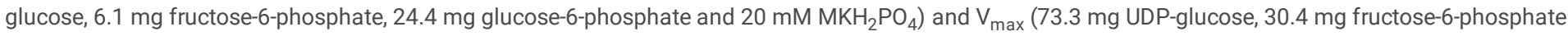
and $121.7 \mathrm{mg}$ glucose-6-phosphate) in a final volume of $200 \mu \mathrm{l}$. This extract was centrifuged at $12,000 \mathrm{~g}$ for $5 \mathrm{~min}$. All reactions were determined by the addition of $100 \mu \mathrm{l}$ of $5 \mathrm{M} \mathrm{KOH}$. F6P was destroyed by heating for $5 \mathrm{~min}$ at $95^{\circ} \mathrm{C}$. After cooling, $1 \mathrm{ml}$ of Anthron reagent $\left(86 \mathrm{ml}\right.$ of $\mathrm{H}_{2} \mathrm{SO}_{4} 18 \mathrm{M}, 20 \mathrm{ml}$ water and $150 \mathrm{mg}$ Anthron (9(10H) Anthracenone)) was added. The reaction free sucrose was quantified with Anthron reagent.

\section{Quantitative real-time qPCR analysis}

The gene-specific primers used are AGPase LSU, StInv6 and StSUS4. Total RNA was extracted from potato leaves using Trisure (Bioline) according to the manufacturer's protocol. Leaf samples were taken at the end of the light period in 2 biological replicates and determined in 3 technical replicates as previously described (Chincinska et al. 2008). Reverse transcription (RT) was performed with the Qiagen Omniscript RT kit according to the manual. Optimized conditions included using oligo (dT) primers for the initial RT reaction. RNA was tested with RNase free DNase (Qiagen) to remove contaminating genomic DNA. RT-PCR experiment was carried out using a SYBR green method. We tested the suitability of actin, as appropriate reference genes, and then actin was used for normalization in all experiments. Samples were collected in technical triplicates with $0.4 \mu \mathrm{l}$ of first standard cDNA in a total volume of $20 \mu \mathrm{l}$ and the mean values of cycle threshold (Ct) were used to calculate the mean normalized expression level (and the Standard Error) of each gene in each cDNA tested relative to the reference gene by Bio-Rad CFX manager. The specificity of the obtained qPCR products was controlled on $1.2 \%$ agarose gel. Primers used for qPCR are the followings:

AGPase fw: gtgtccttcagcgaaaaga; AGPase rev: ctactgccatcgccttcaaa;

Inv6 fw: ctatgcaatcccggctaaca; Inv6 rev: tccatgctgttgttggatca;

SUS4 fw: tattcgtttgaggcctggtg; SUS4 rev: cattgacgttcacacggatg;

Stactin8 fw: ggaaaagcttgcctatgtgg; Stactin8 rev: ctgctcctggcagtttcaa.

\section{Number and weight of tubers per plant}

The number of tubers per plant was determined. The fresh weight of tubers was measured directly after harvest (64, 78and 90 DAP).

\section{Results}

\section{Impact of temperature and cultivar on chlorophyll fluorescence parameters}

It is evident that fluorescence Fo is low in case of unstressed plants and increases in case of stressed plants. Fm is admitted to be low in stressed plants. Between the two fluorescence limits (Fo and Fm), we can deduce the quantum efficiency component that is always less than 1. Quantum yield decreases when the rate of inhibitors increases. For unstressed leaves, the value of $\mathrm{Fv} / \mathrm{Fm}$ is about 0.83 .

Table 1 shows the impact of temperature and cultivar on various chlorophyll fluorescence parameters.

The impact of temperature on various chlorophyll fluorescence parameters was analyzed first during the stolon initiation stage (24 DAP), during this stage and

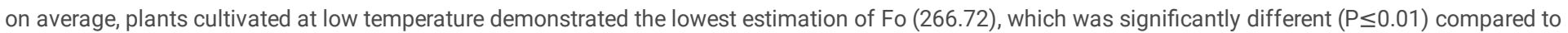
intermediate (290.61) and high temperature (296.94). This indicates that plants cropped in low temperature regime $\left(18 / 16^{\circ} \mathrm{C}\right.$, day/night) seem to be less stressed compared with other temperature conditions. During 49 DAP, the lowest average value of Fo was that of intermediate temperature (368.08), followed by the low temperature condition with (304.66), during this growth stage the low temperature showed also the highest value of Fm with 1513.00 (Table 1). At 64 and 78 DAP, on average, the intermediate temperature condition demonstrated the highest estimation of Fm (Table 1).

Those results showed that during the stolon initiation stage, plants cultivated at low temperature performed better concerning photosynthesis compared to intermediate and high temperature. Later, from 49 DAP, plants cultivated at intermediate temperature showed higher photosynthesis efficiency.

During tuber initiation stage, there was a significant cultivar*temperature interaction for Fo with $\mathrm{P} \leq 0.01$. Data demonstrate that for all studied temperatures, Bellini showed highest values of Fo (Table 1). Analysis shows also a significant cultivar*temperature interaction for Fm. Highest values of Fm were those of Bellini cultivar, especially at high temperature. Those results indicate that Spunta performed better concerning photosynthesis effeciency compared to Bellini. We also observed a significant cultivar*temperature interaction at the level of $5 \%$ for yield of photosynthesis. Spunta behaved better at high and low temperatures, showing a Fv/Fm of about 0.83 in both regimes, and about 0.80 at intermediate temperature (Table 1).

Table 1 shows a significant cultivar*temperature interaction $(\mathrm{P} \leq 0.01)$ for Fo at $30 \mathrm{DAP}$. Bellini registered the highest Fo in all temperatures compared to Spunta.

During the tuber bulking phase (49 DAP) the chlorophyll fluorescence parameters were not significantly impacted by temperature. Later, during the end of the tuber bulking stage 64 DAP, the interaction between cultivar and temperature was statistically significant for Fm. For this trait, the Spunta cultivar had the highest level in all temperature conditions. Spunta showed the lowest Fv/Fm ratio, regardless of the temperature condition. Also at tuber maturation 78 DAP, no significant effect of temperature regimes was shown for chlorophyll fluorescence parameters (Table 1). 
All together these results show that photosynthetic efficiency was higher for Spunta cultivar during different growth stages and that the two cultivars behaved differently according to the temperature condition.

\section{Impact of temperature on soluble sugars and starch in leaves, stems and tubers Leaves}

In order to elucidate temperature responses of potato plants, photosynthetic leaves were analyzed with regard to their carbohydrate contents (glucose, fructose, sucrose and starch) first during tuber initiation stage (30 DAP). Temperature significantly affects hexose and starch accumulation in leaves during this stage. Plants cultivated at low temperature showed maximal amounts of glucose $(0.188 \mu \mathrm{g} / \mathrm{mg} \mathrm{FW})$, followed by high temperature $(0.157 \mu \mathrm{g} / \mathrm{mg} \mathrm{FW})$, which were significantly different $(P \leq 0.01)$ compared to glucose level in leaves at intermediate temperature $(0.041 \mu \mathrm{g} / \mathrm{mg} \mathrm{FW})($ Fig. $1 \mathrm{~A})$. Highest fructose level (Fig. 1B) was noted in the high temperature regime $(0.240 \mu \mathrm{g} / \mathrm{mg} \mathrm{FW})$, followed by low temperature $(0.218 \mu \mathrm{g} / \mathrm{mg} \mathrm{FW})$. Those values were significantly different compared to fructose content in leaves at intermediate temperature $(0.070 \mu \mathrm{g} / \mathrm{mg} \mathrm{FW})$. Sucrose content (Fig. $1 \mathrm{C})$ was higher at low temperature $(0.184 \mu \mathrm{g} / \mathrm{mg} \mathrm{FW})$, followed by high temperature $(0.159 \mu \mathrm{g} / \mathrm{mg} \mathrm{FW})$, lowest sucrose accumulation was recorded at intermediate temperature. Starch accumulation in leaves (Fig. 1D) was higher under low temperature conditions $(0.180 \mu \mathrm{g} / \mathrm{mg} \mathrm{FW})$, followed by high temperature $(0.179 \mu \mathrm{g} / \mathrm{mg} \mathrm{FW})$. Lowest level of starch accumulation was obtained at intermediate temperature $(0.033 \mu \mathrm{g} / \mathrm{mg} \mathrm{FW})$.In the leaf tissue representing the source organ, the content of soluble sugars was not significantly affected by the different temperature regimes during the tuber bulking stage, 49 DAP (Table 2).

However, during the end of the tuber bulking stage (64 DAP), sugar determination as presented in Table 2, revealed significant temperature effects on the amount of glucose accumulated in source leaves. During this growth stage, highest amount of glucose was recorded in the low temperature condition ( 0.219 $\mu \mathrm{g} / \mathrm{mg} \mathrm{FW}$ ), followed by the elevated temperature condition with $0.127 \mu \mathrm{g} / \mathrm{mg}$ FW. Lowest levels of glucose were found in leaves taken from plants cultivated at intermediate temperature $(0.064 \mu \mathrm{g} / \mathrm{mg} \mathrm{FW})$. Also with regard to fructose content, the highest amount was detected under low temperature conditions $(0.387 \mu \mathrm{g} / \mathrm{mg} \mathrm{FW})$, which was statistically different from high temperature $(0.197 \mu \mathrm{g} / \mathrm{mg} \mathrm{FW})$ and intermediate temperature $(0.127 \mu \mathrm{g} / \mathrm{mg} \mathrm{FW})$ conditions.

Also during the tuber maturation phase (78 DAP) the amount of glucose accumulated in leaves strongly depends on the applied temperature (Table 2, level of $5 \%)$. Higher amounts of glucose were observed under high temperature conditions $(0.189 \mu \mathrm{g} / \mathrm{mg} \mathrm{FW})$, which was statistically different compared to low temperature conditions $(0.110 \mu \mathrm{g} / \mathrm{mg} \mathrm{FW})$. The value was lowest under intermediate temperature conditions $(0.069 \mu \mathrm{g} / \mathrm{mg} \mathrm{FW})$. Table 2 shows that at high temperature also the fructose content was highest $(0.238 \mu \mathrm{g} / \mathrm{mg} \mathrm{FW})$, which was statistically different compared to low temperature $(0.153 \mu \mathrm{g} / \mathrm{mg} \mathrm{FW})$.

\section{Stems}

The highest level of glucose in the stem at 49 DAP was recorded at low temperature with $1.549 \mu \mathrm{g} / \mathrm{mg} \mathrm{FW}$, followed by the high temperature regime with 1.369 $\mu \mathrm{g} / \mathrm{mg} \mathrm{FW}$, both of which were significantly different compared to plants cultivated in the intermediate temperature condition with $0.359 \mu \mathrm{g} / \mathrm{mg} \mathrm{FW}$ ( $\mathrm{Table} 2$ ).

Table 2 also shows that the analysis of variance (ANOVA) revealed a significant impact of temperature on fructose in the stem (P $\leq 0.05)$. High and low temperature conditions displayed the highest levels of fructose in stems with respectively 0.214 and $0.187 \mu \mathrm{g} / \mathrm{mg} \mathrm{FW}$. The lowest level of fructose was measured at intermediate temperature $(0.053 \mu \mathrm{g} / \mathrm{mg} \mathrm{FW})$. Table 2 shows a significant impact of temperature on sucrose content in the stem ( $\mathrm{P} \leq 0.01)$ during the end of the tuber bulking stage (64 DAP). Maximum sucrose content was measured in low and high temperature regimes with respectively 0.064 and 0.056 $\mu \mathrm{g} / \mathrm{mg}$ FW. At intermediate temperature, a substantial decrease in sucrose content in the stem tissue was measured $(0.027 \mu \mathrm{g} / \mathrm{mg} \mathrm{FW})$.

In the stem tissue predominantly representing transport phloem, glucose content was not significantly affected by the different temperature regimes during the tuber maturation stage (Table 2).

\section{Tubers}

Regarding the sink organ, soluble sugars content was not significantly affected by the different temperature regimes during the tuber bulking stage (Table 2).

With regard to starch content in tubers, contrary to the accumulation of hexoses, the highest value was recorded in the intermediate temperature condition with $0.683 \mu \mathrm{g} / \mathrm{mg} \mathrm{FW}$ in the end of the tuber bulking stage, followed by high and low temperature conditions with 0.667 and $0.646 \mu \mathrm{g} / \mathrm{mg} \mathrm{FW}$ respectively (Table 2).

In sink organs however, namely in potato tubers, glucose content differed significantly according to the temperature during the tuber maturation stage with the highest amount $(0.155 \mu \mathrm{g} / \mathrm{mg} \mathrm{FW})$ at elevated temperature (Table 2). The same holds true for fructose content in tubers during the maturation phase (with $0.017 \mu \mathrm{g} / \mathrm{mg} \mathrm{FW}$ at high temperature).

Also tuber starch content was highest at high temperature with $1.349 \mu \mathrm{g} / \mathrm{mg} \mathrm{FW}$, and lowest at intermediate temperature with $0.968 \mu \mathrm{g} / \mathrm{mg} \mathrm{FW}$.

\section{Impact of temperature on enzymes activities}

Analysis of variance (ANOVA) of acid invertase activity in stems (Fig. 2A) at 49 DAP revealed a significant effect of temperature on the activity of this enzyme $(\mathrm{P} \leq 0.05)$. The highest activity was detected at low and intermediate temperature with 6.881 and 6.854 nmol*min-1*mg protein-1 respectively.

There were no significant enzyme activities during the end of the tuber bulking stage (64 DAP).

The activity of SPS, the key enzyme of sucrose synthesis, was determined in leaves at 78 DAP (tuber maturation stage) (Fig. 2). 
Surprisingly, the highest SPS activity was detected at low temperature with $9.153 \mathrm{nmol}{ }^{*} \mathrm{~min}-1^{*} \mathrm{mg}$ protein-1 (Fig. 2). Intermediate and high temperature showed very similar activities with 7.191 and 7.806 nmol*min-1*mg protein-1 respectively.

There was a significant interaction between cultivar andtemperature for SPS activity (Fig. 2B). While SPS activity in the Spunta cultivar was not affected by temperature changes, the Bellini cultivar showed the highest SPS activity under low temperature conditions (Fig. 2B).

Thus, sucrose synthesis via SPS as well as sucrose cleavage by acid invertases both are highest under low temperarure.

\section{Impact of temperature and cultivar on the expression patterns of genes related to starch and sucrose metabolizing enzymes}

In order to identify the expression profiles of genes related to starch and sucrose metabolisms and analyze their roles in the tuberization process, transcript levels of three genes were surveyed using quantitative real-time PCR (qPCR) technology (Fig. 3). These three genes showed different expression patterns depending on cultivar and temperature during the tuber initiation stage (30 DAP) (Fig.3A).

We analyzed the expression level of the large subunit of AGPase, which was previously shown to physically interact with the major potato phloem loading sucrose transporter StSUT1(Krügel et al., 2012).

In leaves, the expression level of the AGPase LSU was relatively high in all temperature regimes. Even the Spunta cultivar showed a high expression of $A G P a s e$ at high and low temperature, while, in the intermediate temperature condition, Bellini gave the highest AGPase transcript amount. The expression level of the cell-wall invertase (StInv6) in potato leaves was relatively low under all temperature conditions in both cultivars, except in Spunta growing at the high temperature regime, suggesting the more active role of StInv6 in sucrose conversion in source organs at high temperature (Fig. 3A). At high and low temperatures, the expression level of the SuSy gene StSUS4 remained low compared to AGPase and StInv6 expression with Bellini showing higher transcript levels than Spunta. At intermediate temperature, StSUS4 expression reached the highest levels.

The expression pattern of genes related to starch and sucrose metabolism during tuber bulking phase is shown in Fig. 3B.

Expression of AGPase LSU in Spunta leaves was highest under low temperature conditions, whereas Bellini showed highest levels at intermediate temperature. At high temperature, both cultivars displayed a relatively low level of StInv6 expression, which is consistent with the low invertase activity shown in Fig. 3B. StSUS4 transcript amount is highest at high temperature in both cultivars (Fig. 3B).

The gene expression analysis via qPCR revealed that in the end of the tuber bulking phase the AGPase expression is again highest under low temperature conditions (Fig. 3 C), also suggesting that starch build up in leaves is highest under these conditions.

Also the expression of sucrose and starch metabolizing enzymes was assessed during the tuber maturation phase (78 DAP) in leaves (Fig. 3D). While the StLin6 transcript amount was highest at intermediate temperature in both cultivars, the Bellini cultivar showed high StSUS4 transcript amounts regardless of the temperature (Fig. 3D), suggesting that the sucrose synthase pathway converting sucrose into starch dominates the invertase pathway at this developmental stage in Bellini.

The detailed expression analysis of sugar metabolizing enzymes is not necessarily reflected by the activity measurements shown in Fig. 3 . Whereas invertase activity in leaves is highest under low temperature, no such correlation could be demonstrated regarding the transcript level of invertase StLin6.

\section{Impact of temperature and cultivar on production parameters}

Determination of the total tuber yield per plant at 64 DAP (Fig. 4) revealed a significant impact of temperature on this trait. The highest tuber yield was produced at low temperature with $118.5 \mathrm{~g}$, followed by high temperature with $114.6 \mathrm{~g}$ per plant. Tuber yield decreased at intermediate temperature (75 g).

For the number of tubers per plant (Fig. 4B), analysis of variance ANOVA revealed significant differences between the tested temperature conditions.

Elevated temperature brought about the highest number of tubers with 7.7, followed by low temperature with 7 tubers per plant. The number of tubers decreased in the intermediate condition.

An impact of the temperature on both the total tuber yield and the tuber number per plant was observed. While higher temperature favored total tuber yield, tuber number seemed to be higher with decreasing temperature.

There was a significant cultivar-by-temperature interaction for these production parameters. The Bellini cultivar produced a higher tuber yield compared to Spunta, regardless of the temperature conditions (Fig. 4). Also the number of tubers per plant was generally higher for Bellini than for Spunta when tubers were harvested during the end of the tuber bulking phase (64 DAP).

The production parameters were determined also during the tuber maturation phase (78 DAP, Fig. 5) with significant differences according to the growing temperature. Interestingly, the highest tuber yield was recorded at high temperature, whereas at intermediate temperature, which was assumed to be optimal for tuber production, the lowest yield was recorded for both cultivars at this stage (Fig. 5). The highest number of tubers per plant was observed under low temperature conditions (Fig. 5B). The Bellini cultivar generally produced more tubers and a higher total tuber yield than Spunta, irrespective of the temperature (Fig. 5C, D).

\section{Final yield (90 DAP)}




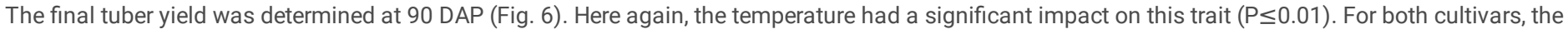
highest tuber yield was recorded at high temperature with $150.8 \mathrm{~g}$, followed by low temperature with $136 \mathrm{~g}$. The lowest yield was maintained at intermediate temperature $(119.876 \mathrm{~g})$. Regarding the number of tubers per plant, low temperature conditions seem to be most favorable for both cultivars (Fig. 6 ). The temperature impact shows significant differences $(\mathrm{P} \leq 0.01)$. Also at $90 \mathrm{DAP}$, the Bellini cultivar produced the highest total yield and the highest tuber number compared to Spunta (Fig. 6C, D).

\section{Correlation}

A correlation study was performed with most of the measured parameters affecting tuber physiology (Table 3).

There was a strong positive correlation among glucose, fructose, sucrose and starch contents in leaves.

A positive correlation was also found between fructose and starch contents in sink organs: fructose and starch levels increase in parallel in potato tubers. Acid invertase activity in the stem was shown to correlate with fructose and starch levels in tubers. This correlation can be interpreted as high sucrose cleavage activity after phloem unloading having a positive effect on fructose and starch accumulation in sink organs.

Acid invertase activity in the stem negatively correlates with sucrose and starch accumulation in leaves. Presumably, high sucrose cleavage activity via acid invertases in the stem tissue could increase sink strength and thereby promote sucrose export from leaves and conversion of transitory starch in leaves into the transport form sucrose.

There was a positive correlation between SPS activity in leaves and glucose and starch accumulation in stems.

A strong positive correlation was shown between acid and neutral invertase activities in tubers.

Acid invertase activity in stems is correlated with the expression level of the invertase gene (StInv6) in leaves.

A positive correlation was also found between final weight and number of tubers per plant.

Most interestingly, final tuber yield as well as tuber number per plant both correlated with the expression level of AGPase and StSUS4 genes in leaves. This indicates a strong impact of sucrose and starch metabolism in source leaves on both tuber initiation and tuber development, both affecting final tuber number and tuber yield.

\section{Discussion}

Mid-early and mid-late maturing Spunta and Bellini cultivars were selected for this experiment in order to study responses to different temperatures (elevated temperature: $25 / 22^{\circ} \mathrm{C}$ day/night, low temperature: $18 / 16^{\circ} \mathrm{C}$ day/night and intermediate temperature: $20 / 18^{\circ} \mathrm{C}$ day/night). Depending on the growth stage, we detected differences among temperature regimes and cultivars. This study demonstrates that growth and production performance of potato plants are strongly affected by temperature.

In general, elevated temperature results in an increase in photosynthesis in source leaves in potato plants. Growth at elevated temperature reduced tuber yield despite an increase in net foliar photosynthesis. This was associated with major shifts in leaf and tuber metabolite profiles (Hancock et al. 2014). These findings are in contradiction with our results showing that at 24 DAP (stolon initiation stage), potato plants cultivated at low temperature were distinguished by a reduced Fo value, indicative of a better photosynthetic performance, compared to plants cultivated at high temperature and intermediate temperature. Fluorescence Fo is known to be low in unstressed plants and to increase in case of stress. It follows that plants cultivated at the low temperature regime $\left(18 / 16^{\circ} \mathrm{C}\right.$, day/night) were apparently less stressed during the stolon initiation stage compared to other temperature conditions. These findings are in agreement with Cutter's (1992) suggestion that environmental factors especially day length and temperature play an important role in tuber initiation although the response varies with varieties. During this stage, Bellini cultivar was more affected by high temperature, showing a stressed behaviour with a Fv/Fm of about 0.80 . Thus, it was showed that growth, chlorophyll fluorescence and photosynthetic performance are affected by drought stress in seedlings of Juglans rootstocks (Liu et al. 2019). Also, highest glucose, sucrose and starch accumulations in source organs have been registered at low temperature. This growth stage was characterized by a remarkable shift between plants cultivated at low and elevated temperature regimes. Surprisingly, plants subjected to intermediate temperature presented the lowest levels of carbohydrates in leaves. The slowed metabolism of plants subjected to intermediate temperature could be explained by an early tuberization compared by the two other regimes, whereas metabolism acceleration in low and elevated temperatures is probably due to the inhibitory impact of low and elevated temperature on tuber initiation. In the same cotext, Borah and Milthorpe (1962) found that the optimal temperature for tuber formation was $20 \mathrm{C}^{\circ}$. At a lower temperature, tuberization was delayed by one week and at higher temperature, tuberization was delayed by three weeks. Results of gene expression levels in leaves during this stage suggest that the expression of sucrose cleaving StInv6 decreases with temperature, whereas starch build-up is highest at low temperature. Thus, decreasing temperature favors the conversion of sucrose into starch during the tuber initiation phase.

The tuber bulking stage (49 DAP) was also distinguished by a shift between low and high temperature regimes concerning carbohydrate metabolism. This shift was registered for stem carbohydrate contents (glucose, fructose and sucrose). The metabolite profile in the stem (49 DAP) was in agreement with acid invertase activity in the stem, showing high activity in plants growing under elevated temperature conditions. Thus, high temperatures reduce partitioning of assimilates to the tubers and enhance partitioning to the haulm (Wolf et al. 1990; Van Dam et al. 1996). Krauss and Marschner (1984) reported that the activities of enzymes involved in starch metabolism were depressed at soil temperatures of $30^{\circ} \mathrm{C}$, resulting in an inhibition of sugar conversion into starch. Gene expression in the tuber bulking phase also depends on cultivar and temperature. Sucrose cleaving enzymes such as invertases and sucrose synthases 
exhibit very different temperature optima at this time point, whereas starch build up via AGPase activity seems to be promoted under low temperature conditions in both cultivars.

It is known that during stolon swelling, a switch occurs from apoplastic to symplastic assimilate unloading in the subapical region of tuberizing stolons which is accompanied by an increase in sucrose concentration in the symplast (Viola et al. 2001). Sucrose is known to induce SuSy expression in potato (Salanoubat and Belliard 1989). Thus an increase in SuSy transcript levels is expected, that is paralleled by a sharp decline in soluble acid invertase activity. During this developmental stage a switch from the invertase-sucrolytic to the SuSy-sucrolytic pathway in the tuberizing stolons is described (Ross et al. 1994) and paralleled by a drop in soluble invertase activity in the subapical region of tuberizing stolons (Viola et al. 2001). Therefore, temperature effect on sucrose levels can thereby also affect the sucrolytic pathway.

At 64 DAP, we also observed a higher photosynthetic performance of potato plants cultivated at low temperature with a Fv/Fm of about 0.83 , while plants exposed to elevated temperature were most stressed with a Fv/Fm of 0.82. This physiological profile was in agreement with plant metabolite profiles, showing high glucose amount in leaves under low and intermediate temperature conditions. The low temperature regime was associated with the highest sucrose content in stems, whereas the intermediate temperature regime produced the highest amount of starch in sink organs. For tuber yield during this stage and with a high stem density (4 to 5 stems per plant), it seems that high temperature induced a higher number of tubers per plant and low temperature produced tubers with higher weight. This could be explained by the study of Güllüoglu and Arıoglu (2009) which showed that higher stem density could result in higher yield, but could also reduce the size of tubers. In the present study, this impact was shown to be stronger at the high temperature regime.

During the tuber maturation stage (78 DAP), elevated temperature allowed potato plants to produce higher amounts of glucose and fructose in source organs. Those results are in agreement with a range of research showing that duration and rate of tuber bulking vary among cultivars and depend on environmental conditions (Ewing and Struik 1992). With regard to hexose accumulation in the stem, the highest amounts of glucose and fructose were recorded at high temperature $\left(25 / 22^{\circ} \mathrm{C}\right.$ day/night). Elevated temperature was associated with the highest amounts of fructose and glucose in sink organs. The highest SPS activity was found in plants grown under low temperature conditions.

No strong correlation was found between starch content and AGPase expression level in leaves. Since the heterotetrameric AGPase enzyme is highly regulated also at the post-translational level (Geigenberger et al. 2005). An increase in starch build up does not necessarily correlate with increased expression of the small and large subunits of AGPase. Elevated temperature increased the total tuber yield, whereas low temperature promoted the number of tubers per plant. These results are similar to those of Gregory (1956), demonstrating that low temperatures, especially low night temperatures, increase the number of tubers per plant. At higher temperatures, when fewer tubers per plant are formed, larger tubers are obtained. While an increase of both day and night temperatures above optimal levels reduce tuber yield, high night temperatures seem to be more deleterious.

Production parameters taken at 90 DAP were similar to those at 78 DAP, with an increase of tuber weight in all temperature regimes and an increase in the number of tubers at intermediate temperature. High temperature produced the highest tuber weight per plant; low temperature produced the highest number of tubers. These results are in disagreement with Rykaczewska (2015) proposition that potato productivity is greatly reduced at temperatures higher than the optimum, as well as with Hawkes' (1992) claim that tuber yield is highly sensitive to elevated temperature in many genotypes.

Borah and Milthorpe (1962) found that the optimal temperature for tuber formation is $20^{\circ} \mathrm{C}$. At a lower temperature $\left(15^{\circ} \mathrm{C}\right)$, tuberization was delayed by one week and at a higher temperature $\left(25^{\circ} \mathrm{C}\right)$, tuberization was delayed by three weeks. In our study, potato plants growing at an intermediate temperature regime $\left(20^{\circ} \mathrm{C}\right.$ at day) were apparently not synchronized concerning growth stages with other temperature conditions. These plants took more days to attain maturity and showed a delay in all growth stages compared to other temperatures. Low and high temperature accelerated tuber maturity. Went (1959); Bodlaender et al. (1964) and Levy and Veilleux (2007) found differences in the response of various cultivars to temperature. In the current experiment, we also found that the tested cultivars behaved differently, depending on the growth stage and also on temperature regimes. At 78 and 90 DAP, Bellini, as a mid-late cultivar, showed the highest number and weight of tubers per plants in all temperature regimes that have been tested, compared to Spunta (mid-early cultivar).

\section{Conclusion}

Our study on the impact of temperature on photosynthesis efficiency, enzymatic activity, gene expression levels, metabolite accumulation, as well as productivity confirmed the view that potato plants respond to temperature depending on cultivar and growth stage. Low temperature, especially low night temperature, enhances tuber initiation and increases the number of tubers produced per plant, while an intermediate temperature regime delays tuber initiation and maturity. Unexpectedly, both cultivars show the highest final tuber yield under elevated temperature. Our results demonstrate that the length of growth stages and growth cycles of potato plants strongly depends on temperature conditions.

\section{Declarations}

Running title: temperature effects on potato tuber physiology

\section{Acknowledgements}

Authors are grateful to Daniel Hey and Andreas Richter for helping in PAM photosynthesis measures, Daniel Wittman and Patrick Schall for protein analysis, Aleksandra Hackelfor excellent technical assistance, Angelika Pötter for attending plant growth and development in the greenhouse. We gratefully acknowledge Hannah Jaspar for proof-reading of the manuscript. The present work was supported by the University of Sousse, Tunisia and the DFG SPP1530 to C.K..The authors declare that there is no conflict of interest regarding the publication of this article to disclose. 


\section{Abbreviations}

HT: High temperature, LT: Low temperature, IT: Intermediate temperature, Temp: Temperature, Prot: Protein, SPS: Sucrose-Phosphate Synthase, SuSy: Sucrose Synthase, AGPase: Adenine Diphosphoglucose Pyrophosphorylase, Invert: Invertase, SD : Short day, LD: Long day

\section{References}

1. Banerjee AK, Chatterjee M, Yu Y, Suh SG, Miller WA, Hannapel DJ (2006) Dynamics of a mobile RNA of potato involved in a long-distance signaling pathway. Plant Cell 18 (12), 3443-3457

2. Berry J, Bjorkman O (1980) Photosynthetic response and adaptation to temperature in higher plants. Annual Review of Plant Physiology and Plant Molecular Biology 31, 491-543

3. Bodlaender KBA, Lugt C, Marinus J (1964) The induction of second growth in potato tubers. European Potato Journal J 7, 57-71

4. Borah MN, Milthorpe FL (1962) Growth of the potato as influenced by temperature. Indian Journal of Plant Physiology 5, 53-72

5. Butler WL (1978) Energy distribution in the photochemical apparatus of photosynthesis. Annual Review of Plant Physiology 29, 457-478

6. Chincinska IA, Liesche J, Krügel U, Michalska J, Geigenberger P, Grimm B, Kühn C (2008) Sucrose transporter StSUT4 from potato affects flowering, tuberization, and shade avoidance response. Plant Physiology 146 (2), 515-528

7. Crafts-Brandner SJ, Salvucci ME (1989) Species and Environmental Variations in the Effect of Inorganic Phosphate on Sucrose-Phosphate Synthase Activity: Reliability of Assays Based Upon UDP Formation. Plant Physiology 91 (2), 469-472

8. Cutter EG (1992) Structure and development of the potato plant., in: Harris, P. (Ed.) The Potato Crop: The Scientific Basis for Improvement. Chapman and Hall, London, pp. 65-161

9. Demmig-Adams B, Adams WW, 3rd (2006) Photoprotection in an ecological context: the remarkable complexity of thermal energy dissipation. New Phytology 172 (1), 11-21

10. Demmig B, Björkman O (1987) Comparison of the effect of excessive light on chlorophyll fluorescence (77K) and photon yield of 02 evolution in leaves of higher plants. Planta 171 (2), 171-184

11. Doehlert DC, Huber SC (1985) The role of sulfhydryl groups in the regulation of spinach leaf sucrose-phosphate synthase. Biochimica et Biophysica Acta 830, 267-273

12. Ewing EE, Struik PC (1992) Tuber formation in potato: Induction, initiation, and growth. Horticultural Reviews 14, 89-198

13. Farrar JF, Williams JM (1991) The effects of increased atmospheric carbon dioxide and temperature on carbon partitioning, sink source relations and partitioning. Plant, Cell and Environment 14, 813-830

14. Geigenberger P, Geiger M, Stitt M (1998) High-temperature perturbation of starch synthesis is attributable to inhibition of ADP-glucose pyrophosphorylase by decreased levels of glycerate-3-phosphate in growing potato tubers. Plant Physiology 117 (4), 1307-1316

15. Geigenberger P, Kolbe A, Tiessen A (2005) Redox regulation of carbon storage and partitioning in response to light and sugars. Journal of Experimental Botany 56 (416), 1469-1479

16. Geigenberger P, Stitt M (1993) Sucrose synthase catalyses a readily reversible reaction in vivo in developing potato tubers and other plant tissues. Planta $189(3), 329-339$

17. Genty B, Goulas Y, Dimon B, Peltier G, Briantais JM, Moya I (1992) Modulation of efficiency of primary conversion in leaves, mechanisms involved at PS2., in: N, M. (Ed.) Research in photosynthesis. Proceedings of IXth International Congress on Photosynthesis, Nagoya, Japan, pp. 603-610

18. Gregory LE (1956) Some factors for tuberization in the potato plant. American Journal of Botany 43, 281-288

19. Güllüoglu L, Arıoglu H (2009) Effects of seed size and in-row spacing on growth and yield of early potato in a Mediterranean-type environment in Turkey. Afr. J. Agric. Res 4 (5),535-41

20. Han H, Gao S, Li B, Dong XC, Feng HL, Meng QW (2010) Overexpression of violaxanthin de-epoxidase gene alleviates photoinhibition of PSII and PSI in tomato during high light and chilling stress. Journal of Plant Physiology 167 (3), 176-183

21. Hancock RD, Morris WL, Ducreux LJ, Morris JA, Usman M, Verrall SR, Fuller J, Simpson CG, Zhang R, Hedley PE, Taylor MA (2014) Physiological, biochemical and molecular responses of the potato (Solanum tuberosum L.) plant to moderately elevated temperature. Plant, Cell and Environment $\mathbf{3 7}$ (2), $439-450$

22. Hawkes JG (1992) History of the potato, in: Harris PM (Ed.) The Potato Crop: The Scientific Basis for Improvement. Chapman \& Hall, London, pp. 1-12

23. Hesse H, Sonnewald U, Willmitzer L (1995) Cloning and expression analysis of sucrose-phosphate synthase from sugar beet (Beta vulgaris L.). Molecular and General Genetics 247 (4), 515-520

24. Huber S.C. Nielson T.H., Huber J.L.A., Phar D.M. (1989) Variation among species in light activation of sucrose phosphate synthase. Plant Cell Physiology 30 (2), 277-285.

25. Kikuchi A, Huynh HD, Endo T, Watanabe K (2015) Review of recent transgenic studies on abiotic stress tolerance and future molecular breeding in potato. Breeding science 65 (1), 85-102

26. Krauss A, Marschner H (1984) Growth rate and carbohydrate metabolism of potato tubers exposed to high temperatures. Potato Research 27, 297-303

27. Krügel U, He HX, Gier K, Reins J, Chincinska I, Grimm B, Schulze WX, Kühn C (2012) The potato sucrose transporter StSUT1 interacts with a DRMassociated protein disulfide isomerase. Molecular plant 5 (1), 43-62

28. Lafta AM, Lorenzen JH (1995) Effect of High Temperature on Plant Growth and Carbohydrate Metabolism in Potato. Plant Physiology 109 (2), 637-643 
29. Levy D, Veilleux RE (2007) Adaptation of potato to high temperatures and salinity - a review. American Journal of Potato Research 84 , $487-506$

30. Liu B, Liang J, Tang G, Wang X, Liu F, Zhao D (2019) Drought stress affects on growth, water use efficiency, gas exchange and chlorophyll fluorescence of Juglans rootstocks. Scientia Horticulturae 250, 230-235

31. Long SP, Humphries S, Falkowski PG (1994) Photoinhibition of photosynthesis in nature. Annual Review of Plant Physiology and Plant Molecular Biology 45, 633-662

32. Marinus J, Bodlaender KBA (1975) Response of some potato varieties to temperature. Potato Research 18, 189-204

33. Midmore DJ, Prange RK (1992) Growth responses of two Solanum species to contrasting temperatures and irradiance levels. Annals of Botany 69, 13-20

34. Müller-Röber BT, Kossmann J, Hannah LC, Willmitzer L, Sonnewald U (1990) One of two different ADP-glucose pyrophosphorylase genes from potato responds strongly to elevated levels of sucrose. Molecular and General Genetics 224 (1), 136-146

35. Navarro C, Abelenda JA, Cruz-Oro E, Cuellar CA, Tamaki S, Silva J, Shimamoto K, Prat S (2011) Control of flowering and storage organ formation in potato by FLOWERING LOCUS T. Nature 478 (7367), 119-122

36. Oquist G, Huner NP (2003) Photosynthesis of overwintering evergreen plants. Annual Review of Plant Biology 54, 329-355

37. Pavlista AD, Ojala JC (1997) Potatoes: Chips and French fry processing., in: D S Smith, J.N.C., W Nip and Y H Hui (Ed.) Processing Vegetables-Science and Technology. Technomac Publishing Co., Lancaster USA

38. Pino MT, Skinner JS, Park EJ, Jeknic Z, Hayes PM, Thomashow MF, Chen TH (2007) Use of a stress inducible promoter to drive ectopic AtCBF expression improves potato freezing tolerance while minimizing negative effects on tuber yield. Plant Biotechnology Journa/ 5 (5), 591-604

39. Rodriguez-Falcon M, Bou J, Prat S (2006) Seasonal control of tuberization in potato: conserved elements with the flowering response. Annual Review of Plant Biology 57, 151-180

40. Ross HA, Davies HV, Burch LR, Viola R, McRae D (1994) Developmental changes in carbohydrate content and sucrose degrading enzymes in tuberizing stolons of potato (Solanum tuberosum). Physiologia Plantarum 90, 748-756.

41. Rousselle P, Robert Y, Crosnier JC (1996) La pomme de terre: production, amélioration, ennemis et maladies, utilisations. INRA Editions, Paris

42. Rykaczewska K (2015) The Effect of High Temperature Occurring in Subsequent Stages of Plant Development on Potato Yield and Tuber Physiological Defects. Potato Research 92, 339-349

43. Salanoubat M, Belliard G (1989) The steady-state level of potato sucrose synthase mRNA is dependent on wounding, anaerobiosis and sucrose concentration. Gene 84 (1), 181-185

44. Stitt M, Lilley R, Gerhardt R, Heldt HW (1989) Metabolite levels in specific cells and subcellular compartments of plant leaves. Methods in Enzymology $174,518-552$

45. Stitt M, Wilke I, Feil R, Heldt HW (1988) Coarse control of sucrose-phosphate synthase in leaves: Alterations of the kinetic properties in response to the rate of photosynthesis and the accumulation of sucrose. Planta 174 (2), 217-230

46. Tiessen A, Hendriks JH, Stitt M, Branscheid A, Gibon Y, Farre EM, Geigenberger P (2002) Starch synthesis in potato tubers is regulated by posttranslational redox modification of ADP-glucose pyrophosphorylase: a novel regulatory mechanism linking starch synthesis to the sucrose supply. Plant Cell 14 (9), 2191-2213

47. Timm H, Yamaguchi M, Clegg MD, Bishop JC (1968) Influence of high temperature exposure on sugar content and chipping quality of potatoes. American Potato Journal 45, 359-365

48. Van Dam J, Kooman PL, Struik PC (1996) Effects of temperature and photoperiod on early growth and final number of tubers in potato (Solanum tuberosum L). Potato Research 39, 51-62

49. Vasquez-Robinet C, Mane SP, Ulanov AV, Watkinson JI, Stromberg VK, De Koeyer D, Schafleitner R, Willmot DB, Bonierbale M., Bohnert H.J., Grene R. (2008) Physiological and molecular adaptations to drought in Andean potato genotypes. Journal of Experimental Botany 59 (8), $2109-2123$.

50. Viola R, Roberts AG, Haupt S, Gazzani S, Hancock RD, Marmiroli N, Machray GC, Oparka KJ (2001) Tuberization in potato involves a switch from apoplastic to symplastic phloem unloading. Plant Cell 13 (2), 385-398

51. Went FW (1959) Effects of environment of parent and grand-parent generations on tuber production by potatoes. American Journal of Botany 46, 277282

52. Winkler E (1971) Kartoffelbau in Tirol. II. Photosynthesevermögen und Respiration von verschiedenen Kartoffelsorten. Potato Research 14, 1-18

53. Wolf S, Marani A, Rudich J (1990) Effects of temperature and photoperiod on assimilate partitioning in potato plants. Annals of Botany 66, 513-520

54. Wolf S, Marani A, Rudich J. (1991) Effect of temperature on carbohydrate metabolism in potato plants. Journal of Experimental Botany 42, 619-625

55. Zeng Y, Wu Y, Avigne WT, Koch KE (1998) Differential regulation of sugar-sensitive sucrose synthases by hypoxia and anoxia indicate complementary transcriptional and posttranscriptional responses. Plant Physiology 116 (4), 1573-1583

\section{Tables}

Table 1 Average effect of temperature and cultivar on chlorophyll fluorescence parameters during different growth stages 


\begin{tabular}{|c|c|c|c|c|c|c|c|c|}
\hline & \multicolumn{3}{|c|}{$\begin{array}{l}\text { Average effect of temperature on chlorophyll } \\
\text { fluorescence parameters during different growth } \\
\text { stages }\end{array}$} & \multicolumn{5}{|c|}{ Interaction temperature-by-cultivar for chlorophyll fluorescence during differ } \\
\hline & 24 DAP & & & 24 DAP & & & & \\
\hline & Fo & Fm & $\mathrm{Fv} / \mathrm{Fm}$ & Fo & & Fm & & $\mathbf{F}$ \\
\hline & & & & Spunta & Bellini & Spunta & Bellini & s \\
\hline Low temp & $266.72^{b} \pm 6.79$ & $1642.22^{\mathrm{a}} \pm 19.62$ & $0.823^{\mathrm{a}} \pm 0.003$ & $248.05 \pm 09.63$ & $285.38 \pm 10.30$ & $1553.77 \pm 072.70$ & $1603.55 \pm 64.72$ & C \\
\hline $\begin{array}{l}\text { Intermediate } \\
\text { temp }\end{array}$ & $290.61^{a} \pm 5.10$ & $1578.66^{\mathrm{a}} \pm 28.01$ & $0.811^{\mathrm{a}} \pm 0.003$ & $289.22 \pm 23.46$ & $292.00 \pm 13.45$ & $1534.27 \pm 123.96$ & $1596.11 \pm 89.72$ & 0 \\
\hline \multirow[t]{4}{*}{ High temp } & $296.94^{a} \pm 7.69$ & $1565.19^{\mathrm{a}} \pm 43.85$ & $0.816^{\mathrm{a}} \pm 0.005$ & $266.27 \pm 13.16$ & $327.61 \pm 08.11$ & $1561.00 \pm 031.45$ & $1723.44 \pm 37.88$ & C \\
\hline & 30 DAP & & & 30 DAP & & & & \\
\hline & Fo & Fm & $\mathrm{Fv} / \mathrm{Fm}$ & Fo & & Fm & & $\mathbf{F}$ \\
\hline & & & & Spunta & Bellini & Spunta & Bellini & s \\
\hline Low temp & $288.13^{\mathrm{a}} \pm 7.16$ & $1641.97^{\mathrm{a}} \pm 47.92$ & $0.82^{\mathrm{a}} \pm 0.00$ & $\begin{array}{l}266.50 \pm \\
9.23\end{array}$ & $309.77 \pm 12.33$ & $1613.44 \pm 085.61$ & $1670.50 \pm 63.75$ & 0 \\
\hline $\begin{array}{l}\text { Intermediate } \\
\text { temp }\end{array}$ & $287.41^{a} \pm 5.71$ & $1586.44^{\mathrm{a}} \pm 30.75$ & $0.81^{\mathrm{a}} \pm 0.00$ & $283.16 \pm 22.82$ & $291.66 \pm 13.73$ & $1563.27 \pm 093.78$ & $1609.61 \pm 69.74$ & 0 \\
\hline \multirow[t]{4}{*}{ High temp } & $297.66^{a} \pm 7.61$ & $1664.80^{\mathrm{a}} \pm 33.48$ & $0.81^{\mathrm{a}} \pm 0.01$ & $277.16 \pm 10.28$ & $318.16 \pm 18.21$ & $1669.16 \pm 128.63$ & $1660.44 \pm 111.96$ & 0 \\
\hline & 49 DAP & & & 49 DAP & & & & \\
\hline & Fo & Fm & Fv/Fm & Fo & & $\mathrm{Fm}$ & & $F$ \\
\hline & & & & Spunta & Bellini & Spunta & Bellini & $\leqslant$ \\
\hline Low temp & $304.66^{\mathrm{ab}} \pm 22.23$ & $1513.00^{\mathrm{a}} \pm 45.90$ & $0.799^{a} \pm 0.019$ & $319.00 \pm 44.26$ & $290.33 \pm 06.81$ & $1598.66 \pm 57.29$ & $1427.33 \pm 67.97$ & 0 \\
\hline $\begin{array}{l}\text { Intermediate } \\
\text { temp }\end{array}$ & $268.08^{b} \pm 07.49$ & $1490.91^{b} \pm 42.60$ & $0.795^{\mathrm{a}} \pm 0.007$ & $243.83 \pm 12.90$ & $292.33 \pm 06.38$ & $1548.00 \pm 37.26$ & $1233.83 \pm 72.26$ & 0 \\
\hline \multirow[t]{3}{*}{ High temp } & $329.83^{a} \pm 09.48$ & $\begin{array}{l}1492.66^{b} \pm \\
6.79\end{array}$ & $0.766^{\mathrm{a}} \pm 0.009$ & $345.66 \pm 04.64$ & $314.00 \pm 16.71$ & $1411.50 \pm 86.58$ & $1573.83 \pm 53.68$ & 0 \\
\hline & 64 DAP & & & 64 DAP & & & & \\
\hline & Fo & $\mathrm{Fm}$ & $\mathrm{Fv} / \mathrm{Fm}$ & Fo & & $\mathrm{Fm}$ & & $\mathbf{F}$ \\
\hline Low temp & $268.83^{\mathrm{a}} \pm 9.51$ & $1647.75^{b} \pm 44.94$ & $0.835^{\mathrm{a}} \pm 0.003$ & $260.83 \pm 06.32$ & $276.83 \pm 07.93$ & $1677.83 \pm 50.67$ & $1617.66 \pm 73.53$ & 0 \\
\hline $\begin{array}{l}\text { Intermediate } \\
\text { temp }\end{array}$ & $287.66^{\mathrm{a}} \pm 3.03$ & $1720.16^{\mathrm{a}} \pm 24.40$ & $0.831^{\mathrm{a}} \pm 0.002$ & $276.50 \pm 12.07$ & $298.83 \pm 10.84$ & $1762.00 \pm 66.26$ & $1678.33 \pm 62.45$ & 0 \\
\hline \multirow[t]{4}{*}{ High temp } & $278.50^{\mathrm{a}} \pm 4.73$ & $1541.83^{c} \pm 25.34$ & $0.820^{b} \pm 0.002$ & $280.00 \pm 10.33$ & $277.00 \pm 30.05$ & $1694.16 \pm 57.90$ & $1389.50 \pm 125.08$ & 0 \\
\hline & 78 DAP & & & 78 DAP & & & & \\
\hline & Fo & $\mathrm{Fm}$ & $\mathrm{Fv} / \mathrm{Fm}$ & Fo & & $\mathrm{Fm}$ & & $F$ \\
\hline & & & & Spunta & Bellini & Spunta & Bellini & s \\
\hline Low temp & $272.16^{\mathrm{a}} \pm 8.92$ & $1504.16^{b} \pm 33.60$ & $0.812^{\mathrm{a}} \pm 0.002$ & $258.83 \pm 6.45$ & $285.50 \pm 15.52$ & $1435.50 \pm 47.00$ & $1572.83 \pm 44.24$ & 0 \\
\hline Intermediatetemp & $282.41^{\mathrm{a}} \pm 5.16$ & $1601.58^{a} \pm 23.00$ & $0.819^{a} \pm 0.004$ & $265.33 \pm 8.94$ & $299.50 \pm 02.97$ & $1592.33 \pm 36.13$ & $1610.83 \pm 17.84$ & 0 \\
\hline High temp & $283.83^{a} \pm 5.39$ & $1563.75^{b} \pm 16.59$ & $0.810^{\mathrm{a}} \pm 0.002$ & $264.16 \pm 3.44$ & $303.50 \pm 08.57$ & $1499.66 \pm 13.14$ & $1627.83 \pm 30.83$ & 0 \\
\hline
\end{tabular}

Means followed by the same letters are not significantly different $(P \leq 0.01)$ according to Duncan's test. Data are means $\pm S E$ (Measurements were made on 6 plants per cultivar per temperature regime per date of measure).

Table 2 Average effects of temperature on carbohydrate content in leaves, stems and tubers (49, 64 and 78 DAP) 


\begin{tabular}{|c|c|c|c|c|c|c|c|c|}
\hline & \multicolumn{3}{|l|}{$\mu \mathrm{g} / \mathrm{mg} \mathrm{FW}$} & \multicolumn{3}{|l|}{$\mu g / m g ~ F W$} & \multicolumn{2}{|l|}{$\mu \mathrm{g} / \mathrm{mg} \mathrm{FW}$} \\
\hline & 49 DAP & 64 DAP & 78 DAP & 49 DAP & 64 DAP & 78 DAP & 49 DAP & 64 DAP \\
\hline & Glucose & Glucose & Glucose & Glucose & Glucose & Glucose & Glucose & Glucose \\
\hline Low temp & $0.111^{a} \pm 0.040$ & $0.219^{a} \pm 0.101$ & $0.110^{b} \pm 0.033$ & $1.549^{a} \pm 0.132$ & $0.027^{a} \pm 0.026$ & $0.029^{a} \pm 0.014$ & $0.122^{a} \pm 0.040$ & $0.128^{a} \pm 0.05$ \\
\hline $\begin{array}{l}\text { Intermediate } \\
\text { temp }\end{array}$ & $0.122^{a} \pm 0.028$ & $0.064^{b} \pm 0.023$ & $0.069^{b} \pm 0.021$ & $0.359^{b} \pm 0.162$ & $0.054^{a} \pm 0.013$ & $0.015^{a} \pm 0.005$ & $0.126^{a} \pm 0.079$ & $0.153^{a} \pm 0.04$ \\
\hline \multirow[t]{2}{*}{ High temp } & $0.126^{a} \pm 0.028$ & $0.127^{a b} \pm 0.047$ & $0.189^{a} \pm 0.053$ & $1.369^{a} \pm 0.148$ & $0.017^{a} \pm 0.013$ & $0.037^{a} \pm 0.013$ & $0.280^{\mathrm{a}} \pm 0.105$ & $0.087^{a} \pm 0.04$ \\
\hline & Fructose & Fructose & Fructose & Fructose & Fructose & Fructose & Fructose & Fructose \\
\hline Low temp & $0.131^{\mathrm{a}} \pm 0.082$ & $0.387^{a} \pm 0.160$ & $0.153^{a b} \pm 0.064$ & $0.214^{a} \pm 0.078$ & $0.041^{a} \pm 0.039$ & $0.047^{a} \pm 0.023$ & $0.016^{a} \pm 0.040$ & $0.015^{a} \pm 0.00$ \\
\hline $\begin{array}{l}\text { Intermediate } \\
\text { temp }\end{array}$ & $0.123^{a} \pm 0.042$ & $0.127^{b} \pm 0.047$ & $0.068^{b} \pm 0.023$ & $0.053^{b} \pm 0.036$ & $0.016^{a} \pm 0.005$ & $0.023^{a} \pm 0.011$ & $0.020^{\mathrm{a}} \pm 0.079$ & $0.012^{\mathrm{a}} \pm 0.00$ \\
\hline \multirow[t]{2}{*}{ High temp } & $0.128^{a} \pm 0.037$ & $0.197^{a b} \pm 0.083$ & $0.238^{a} \pm 0.076$ & $0.178^{a} \pm 0.109$ & $0.030^{a} \pm 0.025$ & $0.058^{a} \pm 0.002$ & $0.024^{a} \pm 0.012$ & $0.007^{a} \pm 0.00$ \\
\hline & Sucrose & Sucrose & Sucrose & Sucrose & Sucrose & Sucrose & Sucrose & Sucrose \\
\hline Lowtemp & $0.211^{\mathrm{a}} \pm 0.039$ & $0.244^{a} \pm 0.067$ & $0.115^{\mathrm{a}} \pm 0.012$ & $0.043^{a} \pm 0.006$ & $0.064^{a} \pm 0.007$ & $0.083^{a} \pm 0.012$ & $0.193^{a} \pm 0.053$ & $0.269^{a} \pm 0.06$ \\
\hline $\begin{array}{l}\text { Intermediate } \\
\text { temp }\end{array}$ & $0.200^{\mathrm{a}} \pm 0.047$ & $0.193^{\mathrm{a}} \pm 0.045$ & $0.069^{a} \pm 0.011$ & $0.027^{b} \pm 0.004$ & $0.027^{b} \pm 0.007$ & $0.069^{a} \pm 0.009$ & $0.277^{\mathrm{a}} \pm 0.070$ & $0.207^{a} \pm 0.06$ \\
\hline \multirow[t]{2}{*}{ High temp } & $0.239^{a} \pm 0.027$ & $0.203^{a} \pm 0.014$ & $0.119^{a} \pm 0.022$ & $0.042^{a} \pm 0.007$ & $0.056^{a} \pm 0.008$ & $0.085^{a} \pm 0.015$ & $0.203^{a} \pm 0.053$ & $0.209^{a} \pm 0.06$ \\
\hline & Starch & Starch & Starch & Starch & Starch & Starch & Starch & Starch \\
\hline Lowtemp & $0.129^{a} \pm 0.050$ & $0.217^{a} \pm 0.056$ & $0.067^{a} \pm 0.014$ & $0.031^{a} \pm 0.006$ & $0.025^{a} \pm 0.004$ & $0.071^{a} \pm 0.010$ & $0.766^{\mathrm{a}} \pm 0.141$ & $0.646^{a} \pm 0.08$ \\
\hline $\begin{array}{l}\text { Intermediate } \\
\text { temp }\end{array}$ & $0.086^{a} \pm 0.016$ & $0.174^{\mathrm{a}} \pm 0.059$ & $0.103^{\mathrm{a}} \pm 0.051$ & $0.060^{\mathrm{a}} \pm 0.019$ & $0.023^{a} \pm 0.003$ & $0.081^{a} \pm 0.011$ & $0.779^{a} \pm 0.109$ & $0.683^{a} \pm 0.05$ \\
\hline High temp & $0.126^{a} \pm 0.014$ & $0.160^{a} \pm 0.018$ & $0.092^{a} \pm 0.020$ & $0.054^{a} \pm 0.020$ & $0.020^{a} \pm 0.002$ & $0.112^{a} \pm 0.037$ & $0.809^{a} \pm 0.088$ & $0.667^{a} \pm 0.10$ \\
\hline
\end{tabular}

Means followed by the same letters are not significantly different $(P \leq 0.01)$ according to Duncan's test. Data are means \pm SE (Measurements were made on 6 plants (leaf tissue) per cultivar per temperature regime per date of measure)

Table 3 Pearson correlation between various characters 


\begin{tabular}{|c|c|c|c|c|c|c|c|c|c|c|c|c|}
\hline Variables & $\begin{array}{l}\text { Acid } \\
\text { Invertase } \\
\text { Stem }\end{array}$ & $\begin{array}{l}\text { Fructose } \\
\text { tuber }\end{array}$ & $\begin{array}{l}\text { Starch } \\
\text { tuber }\end{array}$ & $\begin{array}{l}\text { Neutral } \\
\text { Invert } \\
\text { Tuber }\end{array}$ & $\begin{array}{l}\text { Acid } \\
\text { Invert } \\
\text { Tuber }\end{array}$ & $\begin{array}{l}\text { Final } \\
\text { number } \\
\text { of } \\
\text { tubers }\end{array}$ & $\begin{array}{l}\text { Final weight } \\
\text { of tubers }\end{array}$ & $\begin{array}{l}\text { Fructose } \\
\text { stems }\end{array}$ & $\begin{array}{l}\text { Starch } \\
\text { stems }\end{array}$ & $\begin{array}{l}\text { SPS } \\
\text { leaves }\end{array}$ & $\begin{array}{l}\text { Glucose } \\
\text { leaves }\end{array}$ & $\begin{array}{l}\text { Fructose } \\
\text { leaves }\end{array}$ \\
\hline $\begin{array}{l}\text { Acid } \\
\text { Invertase } \\
\text { Stem }\end{array}$ & 1 & & & & & & & & & & & \\
\hline $\begin{array}{l}\text { Fructose } \\
\text { tuber }\end{array}$ & $0.425^{*}$ & 1 & & & & & & & & & & \\
\hline $\begin{array}{l}\text { Starch } \\
\text { tuber }\end{array}$ & $0.413^{*}$ & $0.488 *$ & 1 & & & & & & & & & \\
\hline $\begin{array}{l}\text { Neutral } \\
\text { Invert } \\
\text { Tuber }\end{array}$ & $0.295^{\mathrm{ns}}$ & $0.063^{\mathrm{ns}}$ & $0.109^{n s}$ & 1 & & & & & & & & \\
\hline $\begin{array}{l}\text { Acid } \\
\text { Invert } \\
\text { Tuber }\end{array}$ & $0.205^{\mathrm{ns}}$ & $-0.030^{\text {ns }}$ & $0.077^{\mathrm{ns}}$ & $0.905^{\star \star}$ & 1 & & & & & & & \\
\hline $\begin{array}{l}\text { Final } \\
\text { number } \\
\text { of tubers }\end{array}$ & $-0.118^{\mathrm{ns}}$ & $0.070^{\text {ns }}$ & $0.132^{\mathrm{ns}}$ & $0.055^{\mathrm{ns}}$ & $0.123^{\mathrm{ns}}$ & 1 & & & & & & \\
\hline $\begin{array}{l}\text { Final } \\
\text { weight } \\
\text { of } \\
\text { tubers }\end{array}$ & $-0.053^{n s}$ & $0.097^{\text {ns }}$ & $0.213^{\mathrm{ns}}$ & $-0.062^{\mathrm{ns}}$ & $0.011^{\mathrm{ns}}$ & $0.624^{*}$ & 1 & & & & & \\
\hline $\begin{array}{l}\text { Fructose } \\
\text { stems }\end{array}$ & $0.019^{\mathrm{ns}}$ & $-0.004^{\mathrm{ns}}$ & $0.084^{\mathrm{ns}}$ & $0.051^{\mathrm{ns}}$ & $0.094^{\mathrm{ns}}$ & $-0.058^{\mathrm{ns}}$ & $0.025^{\mathrm{ns}}$ & 1 & & & & \\
\hline $\begin{array}{l}\text { Starch } \\
\text { stems }\end{array}$ & $0.318^{\mathrm{ns}}$ & $-0.233^{\mathrm{ns}}$ & $-0.147^{n s}$ & $0.064^{\mathrm{ns}}$ & $0.206^{\mathrm{ns}}$ & $-0.117^{n s}$ & $-0.004^{\mathrm{ns}}$ & $0.126^{\mathrm{ns}}$ & 1 & & & \\
\hline $\begin{array}{l}\text { SPS } \\
\text { leaves }\end{array}$ & $-0.306^{\mathrm{ns}}$ & $-0.209^{n s}$ & $-0.139^{\text {ns }}$ & $0.142^{\mathrm{ns}}$ & $0.263^{\mathrm{ns}}$ & $0.129^{n s}$ & $0.077^{\text {ns }}$ & $0.338^{\text {ns }}$ & $0.461^{*}$ & 1 & & \\
\hline $\begin{array}{l}\text { Glucose } \\
\text { leaves }\end{array}$ & $0.015^{\mathrm{ns}}$ & $-0.016^{\mathrm{ns}}$ & $-0.013^{\text {ns }}$ & $-0.085^{n s}$ & $0.013^{\text {ns }}$ & $0.051^{\mathrm{ns}}$ & $0.149^{\text {ns }}$ & $0.217^{\mathrm{ns}}$ & $0.031^{\mathrm{ns}}$ & $0.012^{\text {ns }}$ & 1 & \\
\hline $\begin{array}{l}\text { Fructose } \\
\text { leaves }\end{array}$ & $-0.059^{\mathrm{ns}}$ & $-0.053^{\mathrm{ns}}$ & $-0.079^{\text {ns }}$ & $-0.182^{n s}$ & $-0.080^{\mathrm{ns}}$ & $0.049^{\mathrm{ns}}$ & $0.105^{\mathrm{ns}}$ & $0.150^{\mathrm{ns}}$ & $-0.004^{\mathrm{ns}}$ & $-0.090^{\mathrm{ns}}$ & $0.909 * *$ & 1 \\
\hline $\begin{array}{l}\text { Glucose } \\
\text { stems }\end{array}$ & $-0.166^{\mathrm{ns}}$ & $-0.146^{\mathrm{ns}}$ & $-0.061^{\mathrm{ns}}$ & $0.067^{\mathrm{ns}}$ & $0.108^{\mathrm{ns}}$ & $-0.120^{\mathrm{ns}}$ & $-0.028^{\mathrm{ns}}$ & $0.864^{\star *}$ & $0.262^{\mathrm{ns}}$ & $0.421 *$ & $0.095^{\mathrm{ns}}$ & $0.063^{\mathrm{ns}}$ \\
\hline $\begin{array}{l}\text { Starch } \\
\text { leaves }\end{array}$ & $-0.482^{*}$ & $-0.329^{n s}$ & $-0.260^{\mathrm{ns}}$ & $-0.207^{n s}$ & $-0.109^{\text {ns }}$ & $0.056^{\mathrm{ns}}$ & $0.002^{\mathrm{ns}}$ & $0.038^{\mathrm{ns}}$ & $0.101^{\mathrm{ns}}$ & $0.038^{\mathrm{ns}}$ & $0.298^{\mathrm{ns}}$ & $0.380^{\mathrm{ns}}$ \\
\hline $\begin{array}{l}\text { Sucrose } \\
\text { leaves }\end{array}$ & $-0.401^{*}$ & $-0.298^{\mathrm{ns}}$ & $-0.252^{\mathrm{ns}}$ & $-0.237^{n s}$ & $-0.100^{\text {ns }}$ & $0.030^{\mathrm{ns}}$ & $0.082^{\mathrm{ns}}$ & $0.242^{\mathrm{ns}}$ & $0.181^{\mathrm{ns}}$ & $0.262^{\mathrm{ns}}$ & $0.606^{*}$ & $0.621^{*}$ \\
\hline $\begin{array}{l}\text { AGPase } \\
\text { LSU }\end{array}$ & $0.037^{\mathrm{ns}}$ & $-0.026^{n s}$ & $0.082^{\mathrm{ns}}$ & $0.157^{\mathrm{ns}}$ & $0.251^{\mathrm{ns}}$ & $0.512^{*}$ & $0.354^{\mathrm{ns}}$ & $0.300^{\mathrm{ns}}$ & $0.150^{\mathrm{ns}}$ & $0.424^{*}$ & $0.271^{\mathrm{ns}}$ & $0.177^{\text {ns }}$ \\
\hline Stlnv6 & $0.416^{*}$ & $0.294^{\mathrm{ns}}$ & $0.256^{\mathrm{ns}}$ & $0.156^{\mathrm{ns}}$ & $0.116^{\mathrm{ns}}$ & $0.125^{\mathrm{ns}}$ & $-0.325^{\mathrm{ns}}$ & $-0.005^{\mathrm{ns}}$ & $-0.179^{n s}$ & $0.030^{\mathrm{ns}}$ & $-0.087^{\text {ns }}$ & $-0.161^{\mathrm{ns}}$ \\
\hline StSUS4 & $0.125^{\mathrm{ns}}$ & $0.331^{n s}$ & $0.324^{\mathrm{ns}}$ & $0.086^{n s}$ & $0.002^{n s}$ & $0.403^{*}$ & $0.581^{*}$ & $0.136^{\mathrm{ns}}$ & $-0.038^{n s}$ & $0.059 \mathrm{~ns}$ & $-0.018^{\mathrm{ns}}$ & $-0.042^{n s}$ \\
\hline
\end{tabular}

** $P \leq 0.01$. * $P \leq 0.05$.ns Non significant.

\section{Figures}

\section{Figure 1}

See image above for figure legend.

LT: Low Temperature, IT: Intermediate Temperature, HT: High Temperature 
Fig. $2 \mathrm{~A}$

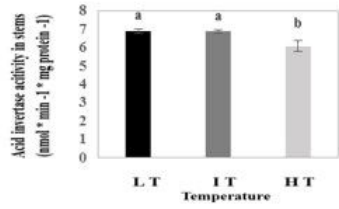

C

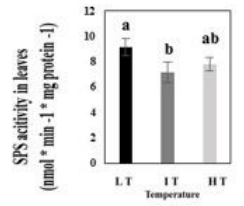

B

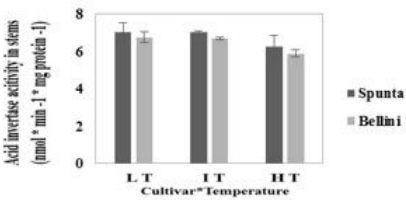

D

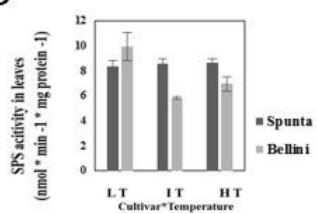

Fig. 2 Acid invertase and sucrose phosphate synthase (SPS) activity depending on temperature.

A, B. Mean effect of temperature and cultivar on acid invertase activity in stem tissue (49 DAP). A, Effect of temperature on acid invertase in stems. B, Interaction between temperature and cultivar for acid invertase activity in stems. Means followed by the same letters are not significantly different $(\mathrm{P} \leq 0.01)$ according to Duncan's test. Measurements were made on six independent stem samples per cultivar per temperature regime per time point and the SE is given.

C, D. Mean effect of temperature and cultivar on SPS activity (78 DAP). C, Effect of temperature on SPS activity in leaves, $\mathbf{D}$, interaction between cultivar and temperature for SPS activity in leaves. Means followed by the same letters are not significantly different $(P \leq 0.01)$ according to Duncan's test. Bars represent mean = standard error of six independent leaf samples.

\section{Figure 2}

See image above for figure legend.

LT: Low Temperature, IT: Intermediate Temperature, HT: High Temperature 


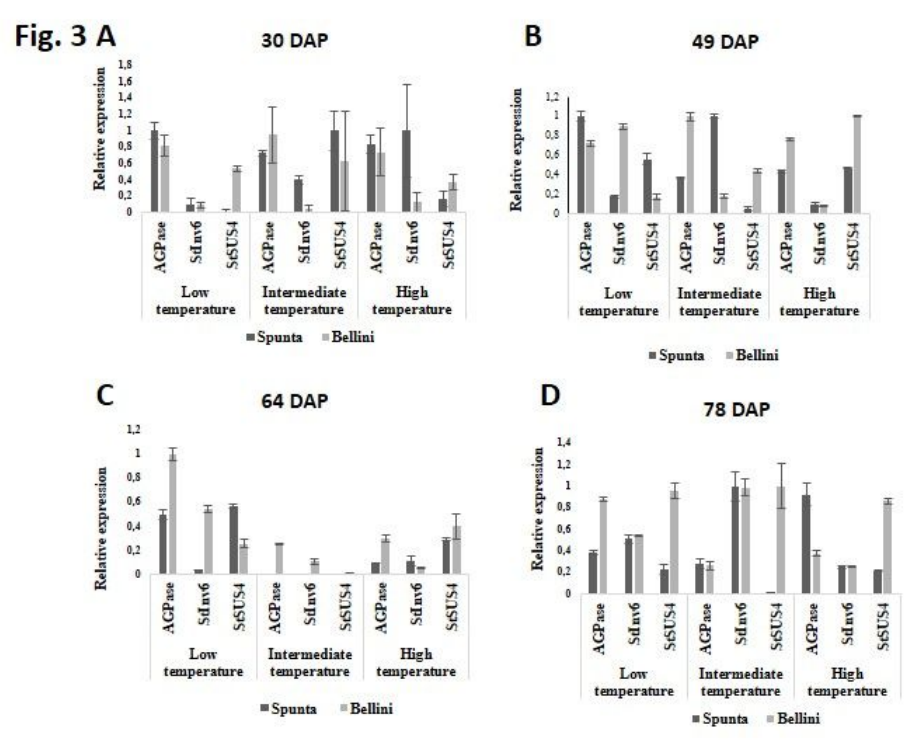
Fig. 3.
The gene expression of starch and sucrose metabolizing enzymes LSU of AGPase, Inv6 and SUS4 in potato
leaves at 30 (A), 49 (B), 64 (C) or 78 (D) DAP. Gene expression in leaf samples was expressed relative to
expression of the reference gene actin. Error bars represent the SEM ( $\mathrm{n}=6)$ of independent leaf samples.

\section{Figure 3}

See image above for figure legend.

LT: Low Temperature, IT: Intermediate Temperature, HT: High Temperature 
Fig. $6 \mathrm{~A}$

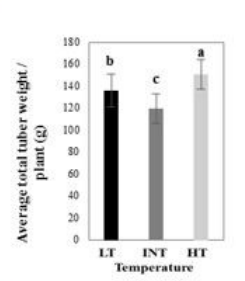

C

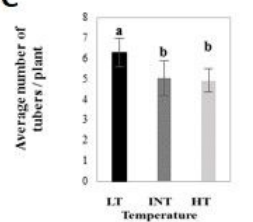

B

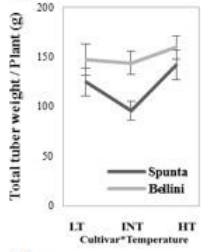

D

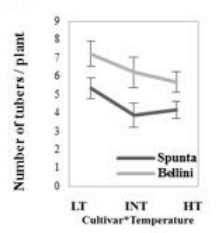

Fig. 4 A-D. Effect of temperature and cultivars on production parameters 90 DAP.

A, Average effect of temperature on total weight of tubers per plant regardless the cultivar. B, Average effect of temperature on total number of tubers per plant regardless the cultivar. C, Interaction between temperature and cultivar for the total weight of tubers. D, Effect of temperature on total number of tubers per plan. Means followed by the same letters are not significantly different $(P \leq 0.01)$ according to Duncan's test. Bars represent mean \pm standard error of six independent leaf samples.

\section{Figure 4}

See image above for figure legend.

LT: Low Temperature, IT: Intermediate Temperature, HT: High Temperature 
Fig. $5 \mathrm{~A}$

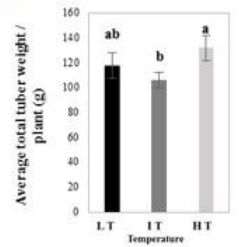

C

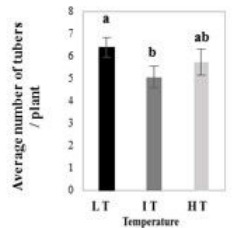

B

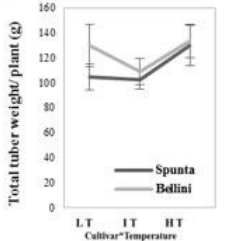

D

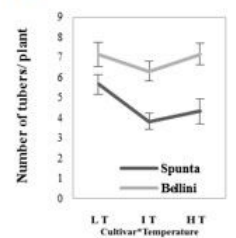

Fig. 5 A-D. Effect of temperature and cultivars on production parameters 78 DAP.

A, Average effect of temperature on total tuber yield per plant regardless the cultivar. B,

Average effect of temperature on total number of tubers per plant regardless the cultivar. C,

Interaction of temperature*cultivar for total weight of tubers. D, Interaction of

temperature ${ }^{*}$ cultivar regarding the number of tubers per plant. Means followed by the same

letters are not significantly different $(\mathrm{P} \leq 0.01)$ according to Duncan's test. Bars represent mean $=$

standard error of six independent leaf samples.

\section{Figure 5}

See image above for figure legend.

LT: Low Temperature, IT: Intermediate Temperature, HT: High Temperature 